\title{
The COVID-19 Pandemic and Latvia-Russia Relations: Landscape for Desecuritization or Further Securitization?
}

\author{
Māris Andžāns * (D) and Una Aleksandra Bērziṇa-Čerenkova \\ Department of Political Science, Riga Stradins University, LV-1007 Riga, Latvia; Una.Berzina-Cerenkova@rsu.lv \\ * Correspondence: Maris.Andzans@rsu.lv
}

\begin{abstract}
This article revisits the traditionally jittery Latvian-Russian relations during the COVID-19 pandemic through the lens of securitization. Though the pandemic might have offered less space for confrontation and possible prospects for differentiation of (de)securitization vectors, the mutual securitization processes have continued in the vein of previous years. Furthermore, they have showed no signs of easing as not only have the traditional issues remained securitized but new thematic areas both related and unrelated to the pandemic have taken center stage. All in all, the pandemic has opened new avenues for securitization, though it had no fundamental impact on the established securitization trends.
\end{abstract}

Keywords: Latvia; Russia; securitization; COVID-19

check for

updates

Citation: Andžāns, Māris, and Una Aleksandra Bērziña-Čerenkova. 2021. The COVID-19 Pandemic and Latvia-Russia Relations: Landscape for Desecuritization or Further Securitization? Social Sciences 10: 323. https://doi.org/10.3390/ socsci10090323

Academic Editor: Andrey Makarychev

Received: 30 June 2021

Accepted: 19 August 2021

Published: 25 August 2021

Publisher's Note: MDPI stays neutral with regard to jurisdictional claims in published maps and institutional affiliations.

Copyright: (c) 2021 by the authors. Licensee MDPI, Basel, Switzerland. This article is an open access article distributed under the terms and conditions of the Creative Commons Attribution (CC BY) license (https:// creativecommons.org/licenses/by/ $4.0 /)$.

\section{Introduction}

The COVID-19 pandemic has impacted every country and every bilateral and multilateral engagement format in one way or another. Borders even between countries exemplifying nothing but mutual trust and amity have been subject to closures. The quest for COVID-19 vaccines and the related vaccine diplomacy have brought about an additional competitive dimension to international affairs. Failures and success stories in containing the pandemic and developing cures have changed the images of states. The economic downturn has exacerbated protectionist instincts and complicated collaborative endeavours and policies. And the list goes on.

The traditionally jittery relations between the neighbouring Latvia and Russia have been no exception to the aforementioned implications. Nor has been the internalization of the bilateral relations-the dynamics surrounding Latvia's Russian speakers.

On the one hand, the pandemic initially decreased the number and the level of political, economic, and societal engagements and thus the room for discord between the two countries. On the other hand, the pandemic has not erased contradictions between the two and might have even exacerbated some of them.

With this in mind, this article looks into the dynamics of Latvia-Russia relations and the related domestic implications in Latvia during the one-and-a-half years of the COVID-19 pandemic. This task is approached via the lens of the securitization theoryhow actors in Latvia and Russia have constructed, reconstructed, or deconstructed each other as a security issue. First, the pre-pandemic years of Latvian-Russian relations are revisited in the light of (de)securitization in order to pave the way to the main focus of this article—securitization processes from early 2020 until mid-2021.

\section{Securitization as a Lens for Conceptualizing Latvia-Russia Relations}

The securitization theory (concept) was developed and first exemplified in the works of O. Wæver at the end of the 1980s and at the beginning of the 1990s (e.g., Wæver 1989; 1995). Since then, the theory has been significantly enriched and extensively tested in various empirical cases. The basic notion of the theory remains intact-it offers a set of 
instruments to trace security formation, i.e., how non-security issues transform in security issues, as well as the reverse process-how security issues transform in non-security issues.

While the main form of conduct in securitization processes is verbal, i.e., as a speech act (Buzan et al. 1998, p. 26), other security articulation forms are also possible and include visual securitization (Hansen 2011, pp. 68-69), securitization via (physical) actions (Wilkinson 2007, pp. 21-22), and securitization via bureaucratic proceedings (McDonald 2008, pp. 568-69). Non-verbal modes can be observed in situations not suitable for verbal expression. While securitization and desecuritization in many ways are similar, the latter is not confined to limiting security language (Wæver 1995, p. 60), i.e., a mere avoidance of invocation of security speech acts. Desecuritization can also occur as management or transformation of security issues (Roe 2004, p. 285), i.e., by continuing the use of security language if necessary but doing so with desecuritization in mind.

Securitization processes can either succeed or they can fail without completion. If a securitization process fails, that situation is considered a mere securitizing move. For securitization to succeed, audience(s) (most often in a form of society) has to accept that a referent object (most often a state or a society) faces existential threats. If the relevant audience(s) subscribe(s) to the arguments of the securitizing actor (most often a state and its representatives), then this paves the way to extraordinary measures to deal with the respective threat (Buzan et al. 1998, pp. 24-26.).

While the examples in brackets in the previous paragraph are state-centric and so is the focus of this study, the range of audiences, referent objects, and securitizing actors has considerably broadened with the widening of security studies to various non-state-centric and non-military issues.

The following section on the background of three decades of ups and downs in Latvia-Russia relations takes a broader conceptualization of the theory. It reviews the main turning points between the two states in terms of securitization and desecuritization. Given that this is a background section, it does not attempt to trace concrete securitization instances; rather, it highlights the main securitization processes over the three decades to prepare the ground for the pandemic period. The main section of the article, devoted to the securitization processes during the global pandemic, goes a step further and traces the main securitization instances.

\section{Latvia and Russia: 30 Years on a Securitized Road}

Throughout the three decades since Latvia regained independence and Russia succeeded the Soviet Union, Latvia-Russia relations have been rather complex and more subtle than often perceived. There have been ups and downs. While the securitization of Latvia from the perspective of Russia has not been as explicit as the securitization of Russia from the perspective of Latvia due to the difference in size and capabilities, conclusions on mutual securitization can nevertheless be drawn. An overview of peaks in securitization is hereby presented in a chronological order.

Against the background of the state (re)formation and international inclusion efforts for Latvia, the first years of bilateral relations were dominated by the issue of the withdrawal of Russia's (formerly Soviet) armed forces, accounting for approximately 60 thousand soldiers (Jundzis 2014, p. 4). They were hesitantly withdrawn by Russia and with notable support from and mediation by Western countries in 1994, while Russia continued to operate the Skrunda Radio Location Station in Latvia until 1998. For Latvia, the withdrawal of Russia's armed forces was a fundamental security issue per se, although it did not lead to major repercussions in bilateral relations.

In the early 1990s, Russia began securitizing the situation of the Russian-speakers in Latvia-both domestically and in international formats. This contributed to a delayed admission of Latvia to the Council of Europe (in 1995). The subject of Russian-speakers ${ }^{1}$, along with allegations of the rebirth of Nazism and rewriting history, became permanent topics and probably the most securitized by Russia over the entire three decades, despite the fact that the "Russian-speakers issue" arose from the Soviet occupation. During the 
Soviet years, the ethnic composition of Latvia was altered considerably-the proportion of ethnic Latvians decreased from $77 \%$ in 1935 to $52 \%$ in 1989, while the proportion of ethnic Russians in the same period increased from 8.8\% to 34\% (Central Statistical Bureau of Latvia 2021b). A significant blow to the bilateral relations leading to securitization was an event in March 1998 in Riga-law enforcement officers used force to stop a demonstration of mostly Russian-speaking retirees. Russia harshly criticized Latvia and imposed unofficial economic sanctions. That event was followed in April by obscure blasts near a synagogue and Russia's embassy, possibly aimed at discrediting Latvia.

As, in 1995, Latvia formalized its goal of joining the European Union and NATO, the road towards NATO in particular became another major issue of securitization from the Russian perspective. It was portrayed as NATO's leaning towards Russia's western borders. However, the period of accession to both organizations coincided with the relative weakness of Russia following the collapse of the Soviet Union and the political and economic transformation processes it implied. Russia, furthermore, had engaged in cooperative vectors with the United States and NATO after 9/11 elevated the threat of terrorism on the global agenda. Therefore, even as Russia regularly expressed its concerns over Latvia's accession to NATO, those statements did not come close to derailing the accession. Partially encouraged by Western partners, Latvia also avoided significant securitization acts towards Russia. Nevertheless, the potential risks emanating from Russia were undoubtedly the main denominator in pursuing membership to NATO and to a lesser extent also the European Union.

The post-accession period to both organizations continued in a generally non-securitized environment. Having reached a perceived sense of security in the Euro-Atlantic institutional space, Latvia attempted to desecuritize its relations with Russia. In 2005-2007 both President and Prime Minister visited Russia, and the Latvian-Russian border treaty was resolved (Latvia gave up its claim to the Abrene district, which had constituted a part of its territory before the Soviet occupation in 1940). The rapprochement with Russia was challenged by the 2008 Russo-Georgian war. It led to a widespread securitization of Russia in Latvia and reinvigorated the perception of Russia as a security threat.

Shortly after the conflict between Russia and Georgia, however, came the global economic and financial crisis and the so-called reset of United States-Russia relations in 2009. It led Latvia to attempts to pragmatize and economize its approach to Russia. Symbolically enough, the president of Latvia travelled to Moscow in 2010 twice and a European standard gauge project (the "Rail Baltica project") was side-lined in favor of a high-speed railway to Moscow, although it did not materialize. The 2010 visits remain the last visits by a high-ranking Latvian politician to Russia as well as in the other direction.

While the failed 2012 referendum on granting an official status to the Russian language in Latvia reinvigorated a sense of insecurity and the resulting securitization of Russia, the game-changer was the Russo-Ukrainian conflict in 2014. Russia was more frequently securitized as a threat not only in the military sense but also beyond. The so-called 'hybrid war' concept was often invoked to encompass such forms as espionage, energy, cyber, and information operations and policies (see, e.g., Bērzinšs 2020 for a conceptualization of the new generation of warfare of Russia). As exemplified by Latvia's post-2014 national security and state defence concepts, it even led to oversecuritization of Russia at the expense of security issues unrelated to Russia (Andžāns and Sprūds 2021, p. 199); e.g., the first of these concepts mentions Russia 65 times (Saeima 2019).

Meanwhile, Russia has continued securitizing Latvia over the situation of Russianspeakers, on allegations of the rebirth of Nazism and the related concept of a perceived revision of history, as well as NATO allies' enhanced presence in the country.

\section{The COVID-19 Pandemic and Latvian-Russian Relations Via the Lens of Securitization}

As exemplified in the previous section, Latvian-Russian relations have been rather complex with securitization and desecuritization vectors interacting and overlapping. Another complexity is the interaction of the two main layers of the (de)securitization 
processes-the international and the domestic. Bearing this interlinkage in mind, this section is further structured along thematic occurrences of securitization thus linking domestic and inter-state relations.

The previous chapter was outlined as a narrative to encompass three decades of the main securitization processes, and this chapter is further structured into five main thematic blocs, i.e., Sections 4.1-4.5. These were devised thematically by the authors of this article, having assessed the main interaction points between Russia and Latvia during the one-and-a-half-years of bilateral relations in question. The first bloc traces securitization possesses directly emanating from the COVID-19 pandemic, while the second bloc looks at the securitization processes that were indirectly impacted by the global pandemic. The remaining three blocs trace the securitization processes that have not evolved due to the effects of the global pandemic (unless distantly impacted by it) but that were nevertheless evident during the one-and-a-half-year period investigated here.

The following tracing of securitization processes is generally based on the primary sources, i.e., audio-visual or written testaments by securitization actors, be they institutions, media outlets, politicians, or bureaucrats, as well as the official documents and other primary sources wherever possible. These primarily serve as a source of quotes illuminating speech acts that were central to the respective securitization moves.

\subsection{The Direct Effects of COVID-19-From Virus to "Sputnik V"}

The pandemic impacted images of countries across the globe and Latvia and Russia were no exception. The situation regarding the coronavirus of the one did not go unnoticed by the other, generally following the previously established patterns of portrayal. Although Latvia was not a focal issue, Russian media channels reported on Latvia and did so mainly either neutrally or negatively (Kleinberga and Andžāns 2020, p. 75). Neutral examples included the news on the so-called "Baltic bubble" travel zone (Tass 2020a). Negative news talked about the ill-preparedness of the education and health institutions and the overall lack of a clear governmental strategy, especially in informing the Russian-speaking population: "Initially, such [COVID-19 information] booklets were issued only in Latvian, which caused an understandable indignation of the Russian-speaking residents of the country" (Izvestia 2021a). Further reports also outlined the economic crisis brought about by the pandemic as well as the uptick in crime and unemployment connected to it across the Baltic states: "Accordingly, one of the strongest fears of an ordinary Latvian, Lithuanian, or Estonian now is losing their job" (Izvestia 2020b).

The failure of the Baltic states in general and Latvia as one of the three to lead an efficient battle against the virus has remained a persistently present topic of COVID-19 news reporting in the Russian media in 2021 as well. Russia's president V. Putin also adhered to this narrative and amplified it via the means of a personal story: "A very good friend of mine, a former colleague of mine, also lived in Latvia almost all his life. He got sick with COVID, and it turned out that the main Latvian center of infectious diseases does not even have an MRI, only an old X-ray, which cannot really show the level of lung damage. There are no medications, nothing. ... We did everything to bring him out [from Latvia to Russia] —we could not. The man died. That is the level of organization, including healthcare" (Putin 2021a).

The political implications of what is portrayed to be poor management of the pandemic in Latvia are also present in the Russian media-sphere: "The growing mutual mistrust between citizens and the authorities in Latvia does not help at all to cope with the crisis" (Lenta.ru 2021a). The article pays particular attention to the statement of the Latvian president E. Levits, in which he named the calls to not wear protective masks a part of hybrid warfare against Latvia. The article states that this led to a crackdown on public dissent: "Obviously, the police received an unofficial order to calculate and fine the participants in the rallies against the restrictions with special diligence, and permits were no longer granted to the events themselves" (Ibid.). 
In the Latvian information space, the Russian approach to fighting COVID-19 has also been presented largely in a negative light. In 2020, Latvian officials called for changes to the visa issuing procedure due to the high infection rates in Russia and Belarus. The Latvian Minister of Foreign Affairs E. Rinkēvičs mentioned that it was worth starting a discussion on "revaluating the residence permit policy", as there was no guarantee that the permit holders would spend two weeks in isolation (Rinkēvičs 2020). Although the minister did not mention Russia explicitly, it is known that the largest proportion of residence permit holders are Russian citizens (Office of Citizenship and Migration Affairs of Latvia 2020). The following year, Latvia's public broadcaster quoted the New York Times investigation claiming that the true numbers of COVID-19 victims are kept secret by Russia (Lsm.lv 2021a) and speaks on the low vaccination pace in the neighbouring country (Lsm.lv 2021b). Another news website quotes the same investigation; however, it places the emphasis differently, highlighting that "Russia has the highest mortality due to the pandemic" in the world (Apollo.lv 2021a). A similar position was echoed by the Latvian Minister of Foreign Affairs E. Rinkēvičs: " . . Covid-19 and the economic situation in Russia is not as rosy as is being portrayed in the propaganda channels" (Rinkēvičs 2021a).

As regards the Russian-produced "Sputnik V" COVID-19 vaccine, the two leading narratives in Latvia were: (1) the controversy surrounding its efficacy (e.g., Apollo.lv 2021b); and (2) the role of "Sputnik V" in the Russian propaganda (e.g., Lsm.lv 2021c).

However, the results of public opinion surveys caused commotion among domestic public and beyond. According to nationally representative surveys, "Sputnik V" would have been the most popular choice among non-Latvians, i.e., Russian-speakers. In February 2021 , it was said to be preferred by $27 \%$ of non-Latvian respondents, as opposed to only $6 \%$ of Latvian respondents (21\% of the latter group preferred the Pfizer-made vaccine) (Latvijas Fakti 2021a, p. 13). In April 2021, "Sputnik V" was again the most popular choice among the non-Latvians, standing at $45 \%$ of those willing to be vaccinated, while again only $6 \%$ of Latvian respondents willing to be jabbed would choose this vaccine (their first choice was again Pfizer at 40\%) (Latvijas Fakti 2021b, p. 11). In both polls, among the respondents and irrespective of nationality, "Sputnik V" came in second behind Pfizer (and ahead of the AstraZeneca and Moderna vaccines, accordingly) (Latvijas Fakti 2021a, p. 11; 2021b, p. 10). Meanwhile, in a poll commissioned by the Latvian government in February 2021, "Sputnik $V^{\prime \prime}$ came first, with $44 \%$ of those respondents willing to choose from a hypothetical pool of vaccine brands (Skds 2021, pp. 10, 54).

The aforementioned, on the one hand, again raised the question of different perceptions of Russia and Russia-related issues among Latvia's Russian-speakers. On the other hand, the aforementioned results were quickly picked up by the Russian media outlets. E.g., a Vzglad article named "The inhabitants of the Baltic countries are dreaming of the Russian vaccine" brought up the survey, talked about the slow rates of vaccination in Latvia and the distrust towards the AstraZeneca vaccine, and quoted the mayor of Rezekne, who stated that his constituents "want to be vaccinated with "Sputnik"" (Vzglad 2021).

\subsection{The Indirect Effects of COVID-19 and 9 May}

A historically critical date for the inter-ethnic relations in Latvia is May 9, the date when the end of World War II is celebrated in Russia. Although not an official holiday in Latvia, the event at a controversial monument in Victory Park usually draws masses of people each year and is seen as the main event uniting the Russian-speakers in Latvia.

Years 2020 and 2021 were no exceptions, although the coronavirus pandemic did account for some differences in comparison with the previous years. In 2020, though in smaller numbers than on previous occasions, people still assembled by the Soviet-era Victory Park monument and the police did little to limit the gathering and enforce full compliance with epidemiological rules. Just a few days earlier, however, on May 4, during the 30th anniversary of Latvia's declaration of independence from the Soviet Union, the public celebrations had been cancelled for epidemiological reasons. It seemed that what was not allowed on May 4-a date of utmost significance for Latvian sovereignty-was de 
facto allowed on May 9-a date strongly associated with the Soviet occupation. The stark contrast between how these two events had been handled caused commotion among the Latvian-speaking members of the society on social media, who also accused the police of catering to Russian interests.

In contrast to the previous year, in 2021, the Riga City council decided to partially restrict access to the monument due to the pandemic. According to the Latvian police, some 20,000 people attended the event (Lsm.lv 2021d). The most controversial aspect picked up by the Russian state media was the restriction on laying flowers directly onto the Monument, asking the visitors to leave their flowers on tables instead. The framing of the Russian authorities of the event was that of popular resistance: "Despite the police cordoning off the Monument to the Liberators in Riga, our compatriots brought flowers and took part in, as they said, actions with portraits of veterans, and on the night of May 9 they spread the flowers they brought around the monument in the shape of a red star", commented the Spokesperson of the Ministry of Foreign Affairs of Russia M. Zakharova (2021a).

The decision was widely discussed in the Russian media-sphere. Lenta.ru reports: "On May 9, the Latvian police blocked access to the monument to Soviet soldiers who liberated Riga from the German invaders." The article quotes K. Čekušins, a member of the opposition Saskana (Harmony) in the Riga City Council: "All this is simply done in order to intimidate people, to alienate them from celebrating Victory Day. I hope that this will not frighten people, our memory is in our hearts" (Lenta.ru 2021b).

\subsection{During the Pandemic but a Pandemic Apart: Military Adversities, Expulsions, and Espionage}

Ever since the Russian-Ukrainian military conflict, Russia has dominated the perception of military threats even more, and the pandemic period offered no softening of things. In September 2020, a new Latvian State Defence Concept was adopted. Russia clearly takes centre stage among the external threats, having been mentioned 19 times in the document. Among other things, Russia is criticized for its "defiant and aggressive military and hybrid activities", and it is judged that for it "... everything that brings no punishment or response is licit" (Saeima 2020, chp. 1.2). In a similar vein, Russia has been presented in other military-defence-related formats.

In 2021, the build-up of Russian armed forces at the border with Ukraine and on the occupied Crimea peninsula attracted international attention and did so also in Latvia. In reaction to the events near the Ukrainian border, among other actors, the Foreign Affairs Committee of the Latvian Parliament issued a statement on the sovereignty and territorial integrity of Ukraine. Commenting on the statement, the Chair of the Committee R. Kols strongly condemned "the Russian Federation's continued aggression in Ukraine and military occupation of Crimea, a Ukrainian territory, which constitutes a serious violation of international law ..." (Kols 2021). The Latvian Minister of Defence A. Pabriks also expressed that "[y]ears of tensions in the region and regular violations of the ceasefire by Russian-backed armed gangs show Russia's desire to stabilize the situation is only in words, not in deeds" (Pabriks 2021).

Russia, in turn, speaks of the growing threat emanating from NATO in the Baltic context, which naturally includes Latvia, e.g., NATO countries' ships with guided missile weapons systematically entering the Baltic Sea (Shoigu 2021a). The minister of Defence S. Shoigu has also pointed out that "over the past three years, the North Atlantic bloc has increased its military activity near the Russian borders ... In Poland and the Baltic countries, the groupings of U.S. troops are being strengthened, ... compared to last year, the intensity of aerial and naval reconnaissance has doubled." As a reaction, according to Shoigu, additional units of Russian armed forces were deployed and operationalized to the western borders of Russia (Shoigu 2021b). The expansion of NATO in Europe, including the Baltics, is a pertinent topic in Russian official communication. In his NBC interview before the 2021 meeting with the U.S. president J. Biden, V. Putin mentioned: "[W]hat was the point of expanding NATO to the east and bringing this infrastructure to our borders, 
and all of this before saying that we are the ones who have been acting aggressively?" (Putin 2021b).

Following the Czech decision to expel Russian diplomats after the local authorities had linked Russian intelligence agents to blasts at Czech ammunition depot back in 2014, the Baltic states, including Latvia, declared a Russian diplomat to be persona non grata in solidarity with Czechia (Ministry of Foreign Affairs of the Republic of Latvia 2021). "Latvia will not tolerate subversive activities on its soil or that of its partners and allies", tweeted E. Rinkēvičs on 21 April 2021 (Rinkēvičs 2021b). Additionally, the persona of the expelled diplomat attracted public attention, as, reportedly, it was Military Attaché R. Ushakov. He had previously been involved in a scandal in a Riga neighborhood, where he was seen having a private party ignoring COVID-19 restrictions and showing inappropriate hand gestures to the neighbors for calling the police (Delfi.lv 2021). The Russian side reacted with a social media remark from M. Zakharova, republished by the official Facebook account of the Russian Embassy in Latvia: "The Baltics are expelling Russian diplomats. The authorities of these countries can have no doubts as to our response. Their diplomats can already start to figure which one of them will have to pack their things" (Zakharova 2021b; Embassy of Russia to Latvia 2021a). An official expulsion notice to one Latvian diplomat along with one Estonian and two Lithuanian colleagues followed a few days later (Ministry of Foreign Affairs of Russia 2021).

Russia has often been securitized over espionage, and in recent years individuals have been sentenced for spying on Russia's behalf in Latvia. Russia continued to be securitized as usual in the annual reports of Latvian intelligence agencies, e.g.,: "As in the previous years, in counterintelligence sphere the most significant threats to the security of our country were posed by Russia's special services" (State Security Service of Latvia 2021, p. 7); and "Activities conducted by Russia's intelligence and security services are aggressive and pose a significant threat to both NATO and E.U. member states' interests and collective security, as well as the national security of Latvia" (Constitution Protection Bureau of Latvia 2021, p. 4).

However, in June 2021, the clearest case of espionage in Latvia as of yet broke out when the Parliament was asked to pull the immunity of the member of Parliament J. Ādamsons of the Saskana (Harmony) party, reportedly based on suspicions of him spying on Russia's behalf. After lifting the immunity, he was detained and arrested on charges of espionage. During the official press conference after the governmental meeting on the issue, the Prime Minister of Latvia K. Karinš stated: "The suspicions against the detainee are very serious" (Lsm.lv 2021e). The Latvian public broadcaster reported: "It is unofficially known that Ādamsons handed over publicly available documents—-various amendments to the laws and information on army procurement and budget-as well as provided information after visiting the country's eastern border and informed about the Baltic Assembly's position against Nord Stream 2. Also, according to unofficial information, he used his parliamentary computer to transmit the data" (Lsm.lv 2021e).

The Russian Tass framed the story in a neutral manner, quoting the Latvian media agency LETA (Tass 2020b). Kommersant also reported in a neutral manner, but included the commentary of J. Ādamsons himself, who called the voting in parliament a "circus" (Kommersant 2021). Gazeta.ru chose a more polemic approach, framing the event as political persecution: "As an MP, he advocated for cooperation with Russia, criticized local nationalists, said that Ukraine itself had lost Crimea, and spoke positively about Vladimir Putin" (Gazeta.ru 2021).

\subsection{Perpetuating Media and Memory Wars}

A widely securitized issue in Latvia has been the presence of Russian state media in the Latvian information space and the consumption of those media by Latvian society, especially Russian-speakers. The Latvian National Electronic Mass Media Council decided on legal grounds to exclude 16 Russian TV channels from the list of channels to be retransmitted in Latvia in February 2021 (National Electronic Mass Media Council of 
Latvia 2021). V. Putin expressed outrage at this decision, calling it exemplary of Western double standards: "Where are the assessments of our Western truth seekers in this regard and assessments of what is happening in Europe with the freedom of speech? No, there are no assessments. It is as if everything is in order, because it is supposedly a fight against propaganda. And what they do is not propaganda. What is it then?" (Putin 2021c). M. Zakharova, in her turn, expressed a cautionary message for Latvia: “ ... I would like to call on the authorities of neighbouring Latvia and Estonia, as well as other E.U. member states, to abandon attacks on the Russian media and the illegal actions against them, because all this causes (in addition to the fact that it lacks inner consistency on a number of positions) damage to the reputation of these states themselves" (Zakharova 2021c).

Later in the year, the fight over the Latvian media space connected to the traditional Russian critique against Latvia for the "rebirth of Nazism" ("fascism"). The latest episode in the controversy had to do with a Russian TV host Vladimir Solovyov. Solovyov had often criticized Latvia over the rewriting of history and glorification of Nazism in his shows (e.g., Solovyov 2018). However, the tables turned in February 2021, when Solovyov stated during his show on the official Russian TV channel "Rossiya 1" that "Hitler was personally a very brave man. ... He had fought, and fought valiantly during World War 1" (Solovyov 2021). The Latvian foreign affairs minister used this incident to ban V. Solovyov entry to Latvia: " . . I I have made a decision to include Vladimir Solovyov, a Russian citizen, in the list of persons undesirable to the Republic of Latvia, establishing a ban on him to enter Latvia for an indefinite period of time. The glorification of Nazism is not acceptable to Latvia" (Rinkēvičs 2021c). The Latvian decision was met with a strong response from M. Zakharova: "We would like Mr Rinkevics to return to reality. If the Latvian authorities really want to fight Nazism, he should stop turning a blind eye to the torchlight marches held by Latvian citizens in honor of the Latvian Legion of Waffen SS. They should stop tearing down and prevent the desecration of monuments to the Soviet soldiers who gave their lives for the liberation of the Baltics from Nazism ..." (Zakharova 2021d). In the vein of this discourse, V. Putin upheld Russia's commitment to criticizing the rebirth of Nazism in his May 9, 2021 Victory Day Parade speech in Moscow, but avoided explicitly mentioning Latvia: "Today we see ... attempts to rewrite history, to justify traitors and criminals, on whose hands is the blood of hundreds of thousands of peaceful people" (Putin 2021d).

\subsection{A New Feature: Wars of Flags}

In May-June 2021, Riga hosted the World Ice Hockey Championship. Though initially it was set to be held in both the Belarussian capital Minsk and Riga, it was allocated to Riga only due to the security situation in Belarus. Unexpectedly, it became a reason for two incidents in which flags were involved.

The first incident, although originally not related to Russia, also became grounds for the securitization of Latvia in Russia. The Mayor of Riga M. Stakis, in the presence of the Latvian Minister of Foreign Affairs E. Rinkēvičs, on a podium of flags representing countries competing at the ice hockey championships in the centre of Riga, changed the official flag of Belarus to the red-white-red flag used by the Belarusian opposition as a response to the forced landing of the Ryanair flight by the Belarusian authorities for the purpose of the arrest of an opposition journalist R. Protasevich (the Belarussian flag was removed from other similar podiums altogether). "These types of symbolic steps sometimes say more than a 101 condemnation or a 101 statement", commented E. Rinkēvičs (2021d). The incident caused the expulsion of the Latvian ambassador and most of the Latvian diplomats from Belarus, and Latvia retaliated in kind. The incident was widely reported and commented on in Russia, ostensibly due to the perception of Belarus as a country very close to Russia and Russia's support for the Lukashenka regime. D. Peskov, the Press Secretary of V. Putin, stated: "We all saw that the flag of Belarus was replaced by a flag that is not the flag of Belarus. This, of course, is quite a blatant event" (Peskov 2021a). The most controversial comment, however, came from the member of the Russian State Duma V. 
Milonov: "We need to support the Belarusians and hang the flag of the Latvian SSR [Soviet Socialist Republic] in front of the Latvian embassy in Moscow ..." (Milonov 2021).

A relatively less well-known incident was related to Russia's flag itself. Similar to the Belarussian flag, that of Russia was exhibited on podiums in Riga, though the Court of Arbitration for Sport ruling had barred Russia's national symbols from all world championships over the state-facilitated doping scam. Following interest from the public, the administration of Riga city decided to replace the flag with that of the Russian Olympic Committee.

Following this occurrence, the official Facebook account of the Embassy of Russia in Latvia published the following statement: "Contrary to their own assurances a week ago about the full legitimacy of using the Russian state flag when decorating the streets of the capital, the city authorities of Riga nevertheless decided, without intelligible arguments, to dismantle it and replace it with the flag of the Russian Olympic Committee. What is it-the inability to keep your word and defend your own principles, banal inconsistency, or a provocative trick for the sake of momentary political conjuncture?" (Embassy of Russia to Latvia 2021b). M. Zakharova tied the decision to Russophobia: "these unworthy manipulations fully fit into the openly Russophobic line pursued by the Latvian ruling elite" (Zakharova 2021e). The reaction of D. Peskov, however, was far less polemic: " ... If it is not the venue of the championship and there are no symbols of the championship, then, of course, we can hardly agree with such a decision of the city authorities ..." (Peskov 2021b).

\section{Conclusions}

The COVID-19 pandemic offers a different context for interaction of Latvia and Russia, as well as for the domestic extension of the bilateral engagement. As this article argues, the mutual securitization processes have not decreased. Rather, both countries remain on a highly securitized path for reasons both related and unrelated to the pandemic.

The one-and-a-half year period reviewed in this article continues the complex relations in which securitization has dominated over desecuritization. It is even safe to argue that this period was one of the most intensely securitized over the past few decades. Given the scope of the issues and actors involved in securitization, the task of capturing the entire issue is complex. Traditional securitization issues remained on the table, while some nuances came as a novelty.

In Latvia, Russia continued to be perceived as a disruptive power posing military and related non-military risks. Meanwhile, Russia continued to perceive and portray NATO and thus also the NATO-allied presence in Latvia in adversarial terms. In addition, and unrelated to the coronavirus, both countries exchanged expulsions of diplomats, and the highest-profile espionage case in Latvia came to light. Additionally, mutual confrontation in the media space and interactions between parallel historical memories seemed to continue, and the latter were also impacted via the restrictions imposed due to COVID-19. The coronavirus yet again illuminated the diversities in Latvian society as studies demonstrated the appeal of Russia's "Sputnik V" vaccine. A novelty in mutual securitization processes arose from sports. During the World Ice Hockey Championship held in Riga, not only was the official Belarussian flag removed but also that of Russia, causing further tensions in the bilateral relations.

It is fairly safe to argue that some of the aforementioned securitization moves would not have happened had the pandemic not evolved as it did. Examples include the restrictions on public events and related commotions, including during the controversial 9 May events; domestic commotions resulting from Russia's vaccine diplomacy; the World Ice Hockey Championship and related wars of flags, had not the coronavirus facilitated the course of the delegitimization of Belarus' political administration and the diversion of the event to Riga alone. At the same time, other high-profile securitization processes would have occurred notwithstanding the epidemiological circumstances-be it Russia posing military threats or spying on Latvia, or, from Russia's perspective, NATO leaning 
on Russia's border and Latvia itself engaging in permanent comprehensive Russophobic endeavours.

Author Contributions: Conceptualization, M.A.; methodology, M.A.; investigation, M.A. and U.A.B.Č.; writing-original draft preparation, M.A. and U.A.B.-Č.; writing-review and editing, M.A. and U.A.B.-Č. All authors have read and agreed to the published version of the manuscript.

Funding: This research received no external funding.

Institutional Review Board Statement: Not applicable.

Informed Consent Statement: Not applicable.

Data Availability Statement: Not applicable.

Conflicts of Interest: The authors declare no conflict of interest.

\section{Note}

1 For a considerable part of Latvia's Eastern-Slavic inhabitants, Russian is the main language of communication. According to the latest census from 2011, Russian was spoken by 37.2\% of inhabitants; in addition, more than three-quarters of Belarussians, Ukrainians, and Poles spoke Russian at home (Central Statistical Bureau of Latvia 2021a).

\section{References}

Andžāns, Māris, and Andris Sprūds. 2021. Securitization and desecuritization of Russia in the national security and defence concepts of Latvia (1995-2020). Journal of International Studies 14: 190-200. [CrossRef] [PubMed]

Apollo.lv. 2021a. Pētījums: Krievijā Ir Vislielākā Mirstība Pandēmijas Dēḷ. 12 April 2021. Available online: https://www.apollo.lv/72 22614/petijums-krievija-ir-vislielaka-mirstiba-pandemijas-del (accessed on 18 June 2021).

Apollo.lv. 2021b. (Republished from LETA). "The Lancet": Vairāku Valstu Zinātnieki Pauž Nopietnas Bažas Par "Sputnik V" Vakcīnas Drošỉbu. 14 May 2021. Available online: https:/ /www.apollo.lv/7248625/the-lancet-vairaku-valstu-zinatnieki-pauz-nopietnasbazas-par-sputnik-v-vakcinas-drosibu (accessed on 18 June 2021).

Bērzin̄š, Jānis. 2020. The Theory and Practice of New Generation Warfare: The Case of Ukraine and Syria. The Journal of Slavic Military Studies 33: 355-80. [CrossRef]

Buzan, Barry, Ole Wæver, and Jaap de Wilde. 1998. Security: A New Framework for Analysis. Boulder: Lynne Rienner.

Central Statistical Bureau of Latvia. 2021a. TSG11-071. Pastāvīgo Iedzīvotāju Tautību Sadalījums pa Statistiskajiem Reǵioniem, Republikas Pilsētām un Novadiem Pēc Mājās Pārsvarā Lietotās Valodas 2011.Gada 1.Martā. Available online: http:/ / data1.csb. gov.lv/pxweb/lv/iedz/iedz_tautassk_taut_tsk2011/TSG11-071.px/table/tableViewLayout1/ (accessed on 1 February 2021).

Central Statistical Bureau of Latvia. 2021b. IRG069. Usually [sic] Resident Population by Ethnicity at the Beginning of the Year. Available online: http:/ / data1.csb.gov.lv/pxweb/en/iedz/iedz_iedzrakst/IRG069.px/ (accessed on 1 February 2021).

Constitution Protection Bureau of Latvia. 2021. 2020. Gada Darbības Pārskats. Available online: https://www.sab.gov.lv/files/2020 parskats.pdf (accessed on 16 June 2021).

Delfi.lv. 2021. Krievijas Militārais Atašejs COVID-19 Laikā Rīgā Ballējas un Rāda Nepieklājīgus Žestus. 13 April 2021. Available online: https:/ / www.delfi.lv/news/national/politics/krievijas-militarais-atasejs-COVID-19-laika-riga-ballejas-un-radanepieklajigus-zestus.d?id=53095863 (accessed on 18 June 2021).

Embassy of Russia to Latvia (Посолство России в Л атвии). 2021a. (On Facebook). Прибалтика Высылает Российских Дипломатов ... 23 April 2021. Available online: https:/ / www.facebook.com/RUSEMBAS/posts/3939955409465451 (accessed on 18 June 2021).

Embassy of Russia to Latvia (Посо лство России в Л атвии). 2021b. (On Facebook). Вопреки Собственным Заверениям Недельной Давности о Полной Правомерности ... 25 Мау 2021. Available online: https:/ /www.facebook.com/RUSEMBAS/posts / 4031 747500286241 (accessed on 18 June 2021).

Gazeta.ru (Газета.ru). 2021. «Как в Сталинском СССР»: Датвийского «Капитана Акулу» Обвинили в Шпионаже на Россию. 10 June 2021. Available online: https:/ / www.gazeta.ru/politics/2021/06/10_a_13628798.shtml (accessed on 18 June 2021).

Hansen, Lene. 2011. Theorizing the Image for Security Studies: Visual Securitization and the Muhammad Cartoon Crisis. European Journal of International Relations 17: 51-74. [CrossRef]

Izvestia (Известия). 2021а. Подкра лся Незаметно: Прибалтика Үшла на Карантин. Страны Балтийского Региона Үчатся Жить вҮсловиях Пандемии. 22 March 2020. Available online: https:/ /iz.ru/989315/vladimir-veretennikov/podkralsia-nezametnopribaltika-ushla-na-karantin (accessed on 18 June 2021).

Izvestia (Известия). 2020b. В Ожидании чуда: Страны Балтии Могут не Перенести Үдар Коронавируса. Экономики $\Lambda$ атвии, Питвы и Эстонии Работают «на Последнем Дыхании». 5 May 2020. Available online: https://iz.ru/1005457/vladimirveretennikov/v-ozhidanii-chuda-strany-baltii-mogut-ne-perenesti-udar-koronavirusa (accessed on 18 June 2021). 
Jundzis, Tālavs. 2014. Krievijas Karaspēka Izvešana no Latvijas 1992-1994: Diplomātiska Uzvara Vai Politiska Piekāpšanās? Latvijas Zinātnu Akadēmijas Vēstis 68: 4-22. Available online: http://ww3.lza.lv/LZA_VestisA/68_3-4/1_Talavs\%20Jundzis_Krievias\%20 karaspeka\%20izvesana.pdf (accessed on 18 June 2021).

Kleinberga, Vineta, and Māris Andžāns. 2020. Latvijas Ārējā Komunikācija un Starptautiskais Tēls COVID-19 Pandēmijas Kontekstā. In Priekšlikumi par Optimālākajiem Dažādu Sabiedrības Grupu Informēšanas Veidiem un Kanāliem, Viltus Zinu Novēršanu, Balstoties uz COVID-19 Izplatības Mazināšanai Noteikto Ierobežojumu Periodā Veiktā Informatīvā un Metodiskā Atbalsta Novērtējumu. Rīgas Stradina Universitāte, Vidzemes Augstskola, Rēzeknes Tehnoloǵiju Akadēmija. pp. 64-76. Available online: https://www.rsu.lv/sites/ default/files/imce/Projekti/VPP_COVID/34_zinojums_final.pdf (accessed on 20 June 2021).

Kols. 2021. Saeima. Ārlietu Komisija Pazinojumā Nosoda Krievijas Militārās Klātbūtnes Palielināšanu Pie Ukrainas Robežām. 21 April 2021. Available online: https://www.saeima.lv/lv/aktualitates/saeimas-zinas/13839.rss.rss/29734-arlietu-komisijapazinojuma-nosoda-krievijas-militaras-klatbutnes-palielinasanu-pie-ukrainas-robezam (accessed on 21 June 2021).

Kommersant (Коммерсантъ). 2021. В Аатвии Депутата Заподозрили в Шпионаже в Пользу РФ. 10 June 2021. Available online: https:/ / www.kommersant.ru/doc/4850166 (accessed on 18 June 2021).

Latvijas Fakti. 2021a. Attieksme Pret Vakcinēšanos Pret COVID 19. Sabiedriskās Domas Aptauja. February 2021. Available online: http:/ / latvianfacts.lv.89-111-52-152.webplace.lv/uploads / Attieksme-pret-vakcinanos-022021.pdf (accessed on 16 June 2021).

Latvijas Fakti. 2021b. Attieksme Pret Vakcinēšanos Pret COVID 19. Sabiedriskās Domas Aptauja. April 2021. Available online: http:/ / latvianfacts.lv.89-111-52-152.webplace.lv/uploads/vakcinacija042021.pdf (accessed on 16 June 2021).

Lenta.ru (Дента.py). 2021a. «Народ Просто Задолбался». Латвия не Справляется с Коронавирусом и Недовольными Гражданами. Почему Она Винит в ЭтомРоссию? 10 February 2021. Available online: https://lenta.ru/articles/2021/02/10 /latvia/ (accessed on 18 June 2021).

Lenta.ru (Дента.py). 2021b. Д атвийская Полиция в День Победы Перекрыла Доступ к Памятнику Советским Воинам. 9 Мау 2021. Available online: https:/ /lenta.ru/news/2021/05/09/riga/ (accessed on 18 June 2021).

Lsm.lv. 2021a. ASV Laikraksts: COVID-19 Upuru Skaits Krievijā Tiek Turēts Noslēpumā. 12 April 2021. Available online: https:/ / www.lsm.lv/raksts / zinas/arzemes/asv-laikraksts-COVID-19-upuru-skaits-krievija-tiek-turets-noslepuma.a400266/ (accessed on 18 June 2021).

Lsm.lv. 2021b. Krievijā Vakcinācija Pret COVID-19 Norit Salīdzinoši Lēni. 4 May 2021. Available online: https: / / www.lsm.lv/raksts / zinas/arzemes/krievija-vakcinacija-pret-COVID-19-norit-salidzinosi-leni.a403168/ (accessed on 18 June 2021).

Lsm.lv. 2021c. "Sputnik V" Efekts. Ko ar COVID-19 Vakcīnu Propagandu Vēlas Panākt Krievija? 15 April 2021. Available online: https:/ / www.lsm.lv/raksts / zinas / zinu-analize/sputnik-v-efekts-ko-ar-COVID-19-vakcinu-propagandu-velas-panaktkrievija.a400535/ (accessed on 18 June 2021).

Lsm.lv. 2021d. Policija: 9. Maijā Pie Uzvaras Pieminekḷa Bija Ieradušies Aptuveni 20000 Cilvēku. 10 May 2021. Available online: https: / www.lsm.lv/raksts/zinas/latvija/policija-9maija-pie-uzvaras-pieminekla-bija-ieradusies-aptuveni-20000-cilveku. a403861/ (accessed on 18 June 2021).

Lsm.lv. 2021e. Saeima piekrīt Ādamsona Apcietināšanai un Kratǐšanai Aizdomās Par Spiegošanu Krievijas Labā. 10 June 2021. Available online: https:/ / www.lsm.lv/raksts/zinas/latvija/saeima-piekrit-adamsona-apcietinasanai-un-kratisanai-aizdomaspar-spiegosanu-krievijas-laba.a408416/ (accessed on 18 June 2021).

McDonald, Matt. 2008. Securitization and the Construction of Security. European Journal of International Relations 14: 563-587. [CrossRef]

Milonov (Спорт-Экспресс). 2021. Депутат Милонов Предложил Повесить у Посолства Датвии Ф лаг Аатвийской ССР. 25 Мау 2021. Available online: https:/ / www.sport-express.ru/hockey/world/news/deputat-milonov-predlozhil-povesit-u-posolstvalatvii-flag-latviyskoy-ssr-1792743/ (accessed on 18 June 2021).

Ministry of Foreign Affairs of the Republic of Latvia. 2021. In a Conversation with the Czech Foreign Minister, the Baltic States Affirm Their Solidarity with the Czech Republic. 26 April 2021. Available online: https://www.mfa.gov.lv/en/news/latest-news /67870in-a-conversation-with-the-czech-foreign-minister-the-baltic-states-affirm-their-solidarity-with-the-czech-republic (accessed on 18 June 2021).

Ministry of Foreign Affairs of Russia (Министерство иностранных дел Российской Федерации). 2021. Об Ответных Мерах в Отношении Латвии, Литвы и Эстонии. 28 April 2021. Available online: https://www.mid.ru/ru/foreign_policy/news/-/ asset_publisher/cKNonkJE02Bw/content/id/4715659 (accessed on 18 June 2021).

National Electronic Mass Media Council of Latvia (Nacionālā Elektronisko Plašsazinas Līdzekḷ Padome). 2021. NEPLP izslēdz no Latvijā Retranslējamo Programmu Saraksta 16 Programmas, Tajā Skaitā “REN TV Baltic" un “NTV Mir Baltic." 9 February 2021. Available online: https:/ / www.neplpadome.lv/lv/sakums/padome/padomes-sedes/sedes-sadalas/neplp-izsledz-no-latvijaretranslejamo-programmu-saraksta-16-programmas,-taja-skaita.html (accessed on 18 June 2021).

Office of Citizenship and Migration Affairs of Latvia (Pilsonības un Migrācijas Lietu Pārvalde). 2020. Statistika: Uzturēšanās Atlaujas. Pilsonības un Migrācijas Lietu Pārvalde. Available online: https:/ / www.pmlp.gov.lv/lv/statistika-uzturesanas-atlaujas-2020 (accessed on 20 June 2021).

Pabriks (Latvijas Aizsardzības ministrija). 2021. Pabriks Pauž Satraukumu par Krievijas Aktivitātēm Ukrainas Robežu Tuvumā. 4 January 2021. Available online: https:/ / www.mod.gov.lv/en/node/9480 (accessed on 21 June 2021).

Peskov (РИА Новости). 2021а. В Кремле Отреагирова ии На Замену Флага Белоруссии на ЧМ по Хоккею в Риге. 25 Мау 2021. Available online: https:/ /rsport.ria.ru/20210525/flag-1733800784.html?in=t (accessed on 18 June 2021). 
Peskov (РИА Новости). 2021b. В Кремле Прокомментировали Ситуациюс Российским Флагом на Площади в Риге. 25 Мау 2021. Available online: https:/ / rsport.ria.ru/20210525/peskov-1733808917.html (accessed on 18 June 2021).

Putin (Президент России). 2021а. Заседание Наблюдательного Совета АНО «Россия-Страна Возможностей». 26 Маrсh 2021. Available online: http:/ / kremlin.ru/events/president/news/65227 (accessed on 18 June 2021).

Putin. 2021b. NBC News. Full Transcript of Exclusive Putin Interview with NBC News' Keir Simmons. 14 June 2021. Available online: https: / / www.nbcnews.com/news/world/transcript-nbc-news-exclusive-interview-russia-s-vladimir-putin-n1270649 (accessed on 21 June 2021).

Putin (TACC). 2021с. Путин Назвал Закрытие Телеканалов на Украине Проявлением Двойных Стандартов. 17 February 2021. Available online: https:/ / tass.ru/politika/10719001 (accessed on 18 June 2021).

Putin (Президент России). 2021d. Парад Победы на Красной Площади. 9 Маy 2021. Available online: http:/ /www.kremlin.ru/ events/president/news/ 65544 (accessed on 18 June 2021).

Rinkēvičs. 2020. Apollo.lv. COVID-19 Dēl Pārskatīs Vīzu Izsniegšanas Kārtības ar Krievijas un Baltkrievijas Pilsoniem. 13 July 2020. Available online: https:/ / www.apollo.lv/7016251/COVID-19-del-parskatis-vizu-izsniegsanas-kartibas-ar-krievijas-unbaltkrievijas-pilsoniem (accessed on 18 June 2021).

Rinkēvičs. 2021a. Ir. Kā Var Runāt ar Krieviju? 12 May 2021. Available online: https://ir.lv/2021/05/12/ka-var-runat-ar-krieviju/ (accessed on 18 June 2021).

Rinkēvičs. 2021b. Edgars Rinkēvičs (On Twitter). In Solidarity with our Czech Allies and Due to the Violations of Vienna Convention ... 23 April 2021. Available online: https:/ / twitter.com/edgarsrinkevics/status/1385549276697202689 (accessed on 18 June 2021).

Rinkēvičs. 2021c. Edgars Rinkēvičs (On Twitter). Pamatojoties uz Imigrācijas Likuma 61.Panta 2.Dalı ... 18 February 2021. Available online: https: / twitter.com/edgarsrinkevics/status/1362353283717861378 (accessed on 18 June 2021).

Rinkēvičs. 2021d. Lsm.lv. Hokeja Čempionāta Karogu Rindā Pie Viesnīcas Baltkrievijas Oficiālo Karogu Aizstāj ar Vēsturisko. 24 May 2021. Available online: https://www.lsm.lv/raksts/sports/hokejs/hokeja-cempionata-karogu-rinda-pie-viesnicas-baltkrievijasoficialo-karogu-aizstaj-ar-vesturisko.a405968/ (accessed on 18 June 2021).

Roe, Paul. 2004. Securitization and Minority Rights: Conditions of Desecuritization. Security Dialogue 35: 279-294. [CrossRef]

Saeima. 2019. Par Nacionālās Drošības Koncepcijas Apstiprināšanu. 26 September 2019. Available online: https://likumi.lv/ta/id/30 9647-par-nacionalas-drosibas-koncepcijas-apstiprinasanu (accessed on 20 May 2020).

Saeima. 2020. Par Valsts Aizsardzības Koncepcijas Apstiprināšanu. 24 September 2020. Available online: https://likumi.lv/ta/id/31 7591-par-valsts-aizsardzibas-koncepcijas-apstiprinasanu (accessed on 20 December 2020).

Shoigu. 2021a. TAСС. Шойгу: Частота Полетов Стратегической Авиации США в Европе Выросла за Семь Лет в14 Раз. 31 Мау 2021. Available online: https:/ / tass.ru/armiya-i-opk/11515927 (accessed on 21 June 2021).

Shoigu. 2021b. Министерство Обороны Российской Федерации. Министр Обороны России Генерал Армии Сергей Шойгу вХоде Поездки на Северный Флот провел Рабочее Совещание в Североморске. 13 April 2021. Available online: https: / / function.mil.ru/news_page/country/more.htm?id=12354311@egNews (accessed on 21 June 2021).

Skds. 2021. Pētījums Par Sabiedrības Attieksmi Pret COVID-19. Latvijas Iedzīvotāju Aptauja. February 2021. Available online: http:/ / petijumi.mk.gov.lv/sites/default/files/title_file/SKDS_Feb2021.pdf (accessed on 16 June 2021).

Solovyov. 2018. СМОТРИМ. ВесьСоловьев. (On YouTube). Латвия Перекраивает Историю. Вечер с Владимиром Соловьевым от 14.02.2018. 14 February 2018. Available online: https:/ /www.youtube.com/watch?v=7w2H11shrk0 (accessed on 18 June 2021).

Solovyov. 2021. Россия1 (On YouTube). Вечер с Владимиром Соловьевым от 17.02.2021. 17 February 2021. Available online: https:/ / www.youtube.com/watch?v=Ipx6_RgvRa8 (accessed on 18 June 2021).

State Security Service of Latvia. 2021. Valsts Drošības Dienests. 2020. Gada Publiskais Pārskats. Available online: https://vdd.gov.lv / $\mathrm{lv} /$ ? rt=documents\&ac $=$ download\&id $=58$ (accessed on 16 June 2021).

Tass. 2020a. ТАСС. Эстония, Латвия и Литва с 15 мая Откроют Внутренние Границы. 6 May 2020. Available online: https: / / tass.ru/mezhdunarodnaya-panorama/ 8404845 (accessed on 18 June 2021).

Tass. 2020b. ТАСС. Премьер Латвии Считает Серьезными Подозрения в Шпионаже Депутата в Пользу России. 10 Јипе 2021. Available online: https:/ / tass.ru/mezhdunarodnaya-panorama/11621195 (accessed on 18 June 2021).

Vzglad (Взгляд). 2021. ЖКители Стран Прибалтики Мечтаюто Российской Вакцине. 1 April 2021. Available online: https: / / vz.ru/world/2021/4/1/1091795.html (accessed on 18 June 2021).

Wæver, Ole. 1989. Security, the Speech Act: Analysing the Politics of a Word. Working Paper no. 1989/19. Copenhagen: Centre for Peace and Conflict Research.

Wæver, Ole. 1995. Securitization and Desecuritization. In On Security. Edited by Ronnie D. Lipschutz. New York: Columbia University Press, pp. $46-86$.

Wilkinson, Claire. 2007. The Copenhagen School on Tour in Kyrgyzstan: Is Securitization Theory Useable Outside Europe? Security Dialogue 38: 5-25. [CrossRef]

Zakharova. 2021a. МИД России (On Facebook). \#ПрямойЭфир Брифинг Официального Представителя МИД России М.В.Захаровой по Текущим Вопросам Внешней Политики, 17:12. Available online: https:/ /www.facebook.com/MIDRussia/ videos / 491523798835045 (accessed on 18 June 2021). 
Zakharova. 2021b. Maria Zakharova (On Facebook). Прибалтика Высылает Российских дипломатов ... . 23 April 2021. Available online: https: / /www.facebook.com/plugins/post.php?href=https\%3A\%2F\%2Fwww.facebook.com\%2Fmaria.zakharova.167\% 2Fposts\%2F10225933130224562\&show_text=true\&width=500 (accessed on 18 June 2021).

Zakharova. 2021c. Министерство Иностранных ДелРоссийскойФедерации. Бричинг Очициального Представителя МИД России М.В.Захаровой, Москва, 26 Мая2021 Года. 26 Маy 2021. Available online: https:/ /www.mid.ru/web/guest/foreign_policy/ news/- / asset_publisher/cKNonkJE02Bw/content/id/4751580 (accessed on 18 June 2021).

Zakharova. 2021d. Министерство Иностранных делРоссийскойФедерации. Бричинг Официального Представителя МИД России М.В.Захаровой, Москва, 18 Февраля2021 года. 18 February 2021. Available online: https://www.mid.ru/brifingi/-/asset_ publisher/MCZ7HQuMdqBY/content/id/4580881 (accessed on 21 June 2021).

Zakharova. 2021е. Министерство Иностранных Дел Российской Федерации. Комментарий Официального Представителя МИД России М.В.Захаровой вСвязис Неприемлемыми Действиями Властей Города Риги в Отношении Государственного Ф лага Российской Федерации. 26 Мay 2021. Available online: https:/ /www.mid.ru/foreign_policy/news/-/asset_publisher/ cKNonkJE02Bw/content/id/4750936 (accessed on 18 June 2021). 